\title{
Thinking Back on Origin of Philosophy - Feelings of Reading History of European Philosophy
}

\author{
Linlin Jiang ${ }^{1} \&$ Xinghua $\mathrm{Li}^{2}$ \\ ${ }^{1}$ School of Marxism, Changchun University of Science and Technology, Changchun, China \\ ${ }^{2}$ Ideological and political Department, Jingdezhen Ceramic Institute, Jingdezhen, China \\ Correspondence: Linlin Jiang, School of Marxism, Changchun University of Science and Technology, 7989 Wei \\ Xing Street, Changchun 130022, China. Tel: 86-431-8558-3045. E-mail: jl1@cust.edu.cn
}

Received: July 2, 2012 Accepted: August 6, 2012 Online Published: August 20, 2012

doi:10.5539/res.v4n4p128 URL: http://dx.doi.org/10.5539/res.v4n4p128

\begin{abstract}
Study of European philosophy is an important impetus for modern Chinese ideological development. For quite a long time, ancient Greek philosophy has been an extremely influential power in European philosophy. High value on study of ancient Greek philosophy and increasing deepening is an important mark of contemporary Chinese ideological maturity. The key to deepen understanding in European philosophy and ancient Greek philosophy is how to see the position of European philosophy and ancient Greek philosophy in development of philosophy.
\end{abstract}

Keywords: European philosophy, ancient Greek philosophy, origin

\section{Philosophy and Thinking Back on Its Development}

As a rational existence, when human being stood out from the great nature, his survival activities no longer simply depended on merely the physiological instinct of the nature, but depended more on his own rational spirit. When human being is faced up with such a series of contradictions as finiteness and infiniteness, relativity and absolutivity, temporality and eternity, reality and ideal and this shore and the other shore, philosophy emerged as the times required and became the highest appeal for human being to surpass self-finiteness and reach an infinite, free and ideal state.

The origin of the word "philosophy" is "philosophia" in ancient Greek, with the original meaning of "love of wisdom". Just as the well known US philosopher Will Durant said, "Science gives us knowledge and philosophy gives up wisdom". Therefore, as for those who study philosophy, understanding and learning philosophy will help them to re-survey themselves and the surrounding world and endow them with more wisdom of life. Maybe, it is in this way that philosophers began to be seen as the pronoun for the people with the most wisdom ever since the ancient Greece. They made reflections on the entire world and, therefore, facilitated the development and progress of the society, as a result of which people showed respect and honor to them. A real philosopher ought to "love wisdom" instead of cracking himself up as a modesty person with "wisdom". Socrates claimed himself as "one who loved wisdom" instead of a "wise person", as knowledge was finite and could be learnt, grasped and occupied, whereas wisdom, as an ideal and free state in human spirit, was infinite and could only be appreciated and loved. In the long-drawn process of historical development of human being, impelled by the primitive nature of thirsting for knowledge of human being, and especially under inspiration and propelling of the natural scientific development, a multitude of philosophers have illustrated their pursuit and probe of the nature of philosophy with thousands of years. Thereby, the three major morphologies of philosophy which have the most abundant content and the most profound influences in the process of historical development came into being, namely, Indian philosophy created by the Ganges civilization, Chinese philosophy created by the Yellow River civilization and European philosophy originating from the ancient Greek civilization. Simply speaking, what philosophy history describes is a history of philosophical thought until today. As a kind of relatively independent ideology, philosophical thoughts at different periods have their own relative complete extension and evolvement process. Thus, history of philosophy is a developmental history of problems. It is not simple bags-of-words of history data which have lapsed, but is an animated developmental process of movement with life and is imbued with rational brilliance of human being. Therefore, people's love in philosophy should be rooted in the zeal in the history of philosophy. History of philosophy is a rational pivot for human being to love 
wisdom and obtain wisdom.

\section{European Philosophy and Reflection on Its Origin}

A general survey on the three major philosophical systems created by human being, European philosophy has more abundant theoretical content, more nature development pattern and more profound influences and has been, as yet, the most typical philosophical system. It is true that China and India have ever created glorious ancient civilization. Nevertheless, the Chinese philosophy and Indian philosophy still remain at a level as in the ancient and have not formed their own independent modern philosophy. By contrast, European civilization has displayed a long-run momentum of development. The Christian philosophy was born out of the ancient Greek philosophy, the European modern philosophy was born out of the Christian philosophy and Marxism and contemporary European philosophy were born out of the modern European philosophy. As a matter of fact, the above conventionalized standard for classification of European philosophy, Indian philosophy and Chinese philosophy is basically a concept in European philosophy. And even to a certain extent, the history of Chinese philosophy was separated from the vast ancient thought materials in the mode of European philosophy at the very beginning. In the face of the turbulent tide of the European philosophy, the world was unable to evade and the ancient Chinese philosophy also had no way to resist as we had never possessed a modern civilization and contemporary civilization as brilliant and glorious as the European philosophy. In the face of the harsh reality, Chinese civilization again manifested its enormous inclusiveness. That is, since we were less competent, we need to learn the advantage from the foreign countries and learn to study European philosophy. Understanding European philosophy and studying the history of European philosophy becomes an important impetus for development of modern Chinese thought, which, actually, is a response made by Chinese people to the modern challenges from the western. The most direct evidence is that the history of European philosophy and its original works are the main curriculum in teaching and learning of the profession of philosophy in China and become the basic content in the teaching system of philosophical subjects.

Ancient Greece is the place of birth of European philosophy and all kinds of thought theories may find their origins in ancient Greek philosophy. Ancient Greek philosophy refers to the Greek philosophy between BC $6^{\text {th }}$ Century and $\mathrm{AD} 5^{\text {th }}$ Century and the following Roman philosophy. Hence, it is also called ancient Greek-Rome philosophy. As the first development period of the history of European philosophy, ancient Greek philosophy began in Greece in BC $6^{\text {th }}$ Century when Greece was a slave society with relatively developed economy and its culture got rapidly developed under the influences of Egypt and Babylon in the east. Under such a background, the ancient Greek philosophy came into being from the primitive religious myth, grew out of nothing and became the earliest theoretical and ideological form in the history of human being. Afterwards, a multitude of philosophers began to explore all truths underlying with a sharp vision. Different from the traditional "theory that man is an integral part of nature" in China and the mode of thinking that man and the nature is one whole, ancient Greek philosophers stand on the opposite of the world to observe and ponder over it. They say the nature nothing more than a study object, and just as the globe is held in the hand to observe the world, man is separated with the nature.

Prior to birth of the wise men, a lot of early natural philosophers appeared in the ancient Greece who regarded the primitive things in the world as the primary object of exploration. The earliest natural philosopher was Milesian school, and then Pythagoras and Pythagoras School, Heraclitus, Eleatic School and atomists. Among all these philosophers, the atomology philosophy represented by Democritus was "summit and synthesis of Pre-Socratic philosophy." The atomology philosophy was also seen as the highest achievement of the ancient Naive materialism. When the wise men appeared, the ancient Greek philosophers transferred their interest from study on the nature to study on man. A significant transition occurred to the spirit and philosophy of the ancient Greek people. They broke through the traditional concepts in the Classical era and before and set up the subject consciousness, which enabled the ancient Greek philosophy to take a qualitative leap.

When Protagoras bellowed out the great proposition that "Man is the scale of all things", the subject consciousness of philosophy came into being and was established, as a result of which earthshaking changes took place in the entire spiritual world of the Greek people. Socrates is the successor of the subject consciousness which was firstly advocated by the wise men. Nevertheless, contrary to the wise men, the subject consciousness of Socrates was collectivism and rationalism instead of empiricism, individualism. He believed that it was possible to know everything and the objective truth did exist. By the years of Socrates, the ancient Greek philosophy was split and then the ancient idealism philosophy came into being that was opposite to the Naive materialism. Shortly afterwards, Plato constructed the philosophical system of theoretical idealism. The theoretical philosophy by Plato went through the evolvement process of three periods, namely, early, middle and late periods, which could be seen as a model of cognitive evolution of human being. Afterwards, Aristotle 
inherited and developed the objective idealism of Plato. He combined idea and empirical fact into one whole, established an enormous philosophical system and put forward the scope of entity, which entitled him to be a synthesizer of the ancient philosophy.

The ancient Greek philosophy attained the highest prosperity at the period of Aristotle and then declined radically. After the three wise men of the ancient Greece, pure Greek philosophy gradually became a bygone. When the Roman era approached, although Roman people possessed powerful political competence, they were unable to establish an independent philosophy and philosophy at the Roman era was nothing more than extension of the ancient Greek philosophy. It is true that other schools of philosophy had emerged, such as, the Epicureans School, the Stoic School, the Skeptic and the Neo-Platonism, but they were nothing but specific application and compromise of antecedent philosophy. It is also true that spark of rationalism had flashed during this period, Greek philosophy inevitably went down to vulgarity. With combination of philosophy and religion, the rationalism culture created by the ancient Greek philosophers began to transfer to religious fideism culture and philosophy ultimately descended to dependency of religion. With decline of the ancient Greek culture and emergence of Christian, the Polytheism in the Greek-Roman world was replaced by the Christian-Kathenotheism and the ancient Greek philosophy was also replaced by Patrology in Christian.

\section{Concluding Remarks}

Tracing the origin of philosophy, ancient Greek philosophy is the origin of the modern western philosophy and it is a source of root that the western philosophy differs from Chinese philosophy. It is exactly owing to the nature of ancient Greek philosophers to thirst for knowledge and make explorations that European philosophy was able to take root and sprout and continue to be prosperous, standing out in all the civilizations in the world. It is also because of the philosophy tradition itself which originated from the ancient Greece that the modernity of the western civilization possessed its great power to wreck any dissident tradition. During each important period in the history of western ideological development, inheritance and use of the ancient Greek philosophical heritance are both critical elements for evolvement and development of thoughts. The miraculous brightness of ancient philosophical thought and the traditional inherent tension of the ancient Greek philosophy flash gleamingly in either exploration of the realistic political technique by the politicians in the Roman Empire or reflection of existing problems by the philosophers in the middle century and re-defining of the natural order by the modern philosophers. As a matter of fact, ancient European philosophy is philosophy created by the Greek people and all kinds of philosophy later was nothing more than extension and variant of the ancient Greek philosophy. The fundamental issue of ancient Greek philosophy is, all along, the actual focus of philosophy. In this sense, it is owing to creation of the Greek people that philosophy today is philosophy and ancient Greek philosophy is the source of life of all kinds of philosophy.

When the last Neo-Plato academy in the world was closed by the Christian Roman Emperor who converted to the Monotheism, the ancient Greek philosophy which had plenty of ideas had already had a history of more than a thousand years. It is exactly during that period that the earliest spiritual home of human being was built owing to the continuous exploration and reflection of a multitude of ideologists. The various viewpoints later in the European philosophy may find their primitive morphology in the various forms of philosophy during this period. As a mystical country, the remote Greece not only has accommodated a large number of gods, but has also given birth to a lot of great philosophers. Just as the Greek myth, the philosophical thoughts of these philosophers have undergone a history of more than two thousand years and are still suffusing in the world, accompanying with birth, pursuit, thinking and death of one generation after another. Therefore, a multitude of people who study philosophy are imbued with dream of the ancient Greek philosophy and no wonder that they are bound up in pursuing the ancient Greek philosophy.

\section{References}

Gao, W. X. (1994). European Philosophy Special Subject Study. Jilin People's Publishing House.

Li, M. (2009). Ancient Greek Philosophy and We. World Philosophy, 5.

Liu, W. Y. (1982). Several issues of the History of Comparative Philosophy. Journal of Lanzhou University (Social Sciences), 3.

Shi, Z. Y. (1984). Knowledge Is Power - Note of Learning of European Philosophical History. Hebei Academic Journal, 3.

Wang, Z. L. (2008). Brief Analysis of Historical Periods and Major Characteristics of Ancient Greek Philosophy. Legal System and Society, 28.

Yang, F. X., \& Wang, T. (2010). Relationship of Source of Course between Ancient Greece and Western 
Civilization. Journal of Suihua University, 3.

Zhang, C. K. (2004). The History and Logic of the Development of the Ancient Greek Philosophical Categories. Journal of Anhui University (Philosophy \& Social Sciences), 3.

Zhang, Z. W. (2002). A History of Western Philosophy. China Renmin University Press. 